\title{
An Emperical Study on Export of Developing Asean Country
}

\author{
Sameer Kumar \\ Research Scholar, Dept. of Commerce, H.N.B. \\ Government PG College Naini, CSJM University, \\ Kanpur, Uttar Pradesh, India
}

\author{
Dr. Subarana Sarkar Mukerjee \\ H.N.B. Government P.G. College Naini Allahabad, \\ Uttar Pradesh, India 2CSJM University, Kanpur, \\ Uttar Pradesh, India
}

\section{ABSTRACT}

Exports have played a more and more important role in India's economic development and ASEAN Country. This paper critical analyses the performance of India's exports and the various economic factors in different year which have contributed to its growth. No such model has been available in the literature that estimates the performance India's exports to Southeast Asia and the world. This measurable investigation demonstrates that India's exports execution grew essentially amid the post-change period and there has been a noticeable change in the value, composition and direction of India's exports. The study complete that the relationship between India's exports to Southeast Asia and India's exports to the world too India's exports to Southeast Asia is more vital.

Keywords: Exports, GDP, Correlation, Regression

\section{INTRODUCTION}

Export assumes a vital part in formative procedure of any country and it is invigorating development and export could be profitable for the economic to pick up wealth and end up plainly prosperous. There is a positive connection between trade development and rate and the GDP of any country [8, 1]. Different researchers have proposed that exports can be exceptionally viable in advancing monetary development of country. Since the country need to pay for their imports which they cannot create at home consequently trade assume and altogether part in global trade $[5,11]$. So send out prompt the product specialization and clears route for quick advancement of the economic. In this manner send out invaluably affect the economic development of the country and exports extension can prompt higher monetary development, increment the work openings in the economy and subsequently the improvement and the welfare of the social orders.

India is creating economic profile has allured the South East Asian to faster conclusion engagement with India at regional at multilateral level in the making scene. ASEAN money related perspectives have the most essential trade to GDP extent. India has in effective manner get a place of execution at the overall stage. As India and ASEAN the 2 common market can be merged together to give a market of huge potential for advancement and in storm cellar by both residential and global financial specialists. Association of South East Asian Nation established on 1967 in Bankok charter. That time Indonasia, Filipiens, Malasia, Thailand, Viyatnam, Combodia, Singapore, Myanmar 10 coutry members. India is a complete member on 23july 2010 of ASEAN [2].

Rusia and China also added in this association. India and ASEAN to promote closer commitment with India at regional and mutual level is India's growing economic profile. Realizing the fact that both region are complementary rather than competitive with each other. Various initiatives have been taken to overcome the barriers in interactions between India ASEAN like sitting up of ASEAN business council, India ASEAN business summit and India ASEAN negotiation committee much more. India trade in goods 
agreement has been another landmark development in greater combination of Indian economy with ASEAN. The share of Asian countries in the total export of India has increased from 1990-91 to 2013. Considering this fact it becomes imperative to study the significance of the association between India's export to South East Asian countries and Indians total export to the world. In the presents action we have discussed the direction of India's export the growth rate of India's export to major reasons export to OECD(organization for economic co-operation and development) countries, export to OPEC(organizations of petroleum exporting countries) countries, export to eastern Europe, export to the ASEAN countries [3]. In order to this research work experts focus analysis of India's export to ASEAN country.

\section{RELATED WORK}

A number of researchers accepted that ASEAN Country have been contains information about growth criteria and effect to different structure between valuable aspects. This study is based upon secondary sources of data which has been collected from UNCOMTRADE statistics division at 1 digit SITC(Standard International Trade Classification) Rev. 2 for the period 1991-2013.Other sources of data include IMF-Foreign Trade Statistics yearbook and ASEAN Merchandise Trade Statistics Database.

In 2008, Rupa Chanda and G. Sasidaran [9] inspects the reason - India's developing enthusiasm for confining different sort of local and valetirial concurrence with asian economy the examination complete up by taking a gander at the prospects for future particular exchange understanding by India and the different issues and intrigue that should spare India's future territorial activities to guarantee the acknowledgment of its long term economy key and topographically objective. In 2005, Razeen Sally and Rahul Sen [10] investigate the exchange approaches in South East Asian country in their more extensive asian and worldwide setting. In 2005, Suparna K. portrayed the ecnomical situation in the Asia pacific reason and a smaller scale review of the exchange certain capability of a concession to exchange benefit among individual from ASEAN and India.

In 2008, Mukul Asher and Amithtendu Palit [11], clarified and investigate India's look east approach. India's economical engagement with Southeast Asia has exhausted fast partner since the mid 1990's stock exchange amongst India and ASEAN. Expanded in term of ware piece. In 2007, Lee [2] recommends the advancement of exchange and financial plan amongst India and Southeast Asia must be steered inside the larger procedure of monetary and conciliatory trade in Asia.

In 2016, Naveen S. [3] highlighted with statistical analysis of India's export to Southeast Asia the southeast Asia is phenomenal success as a group of model and industrial and trading nation has open new avenues for renown India, bilateral trade between India and ASEAN and analytical study(2015). The upshot is the Indoasian trade has shown the significant association during the period of study.

A complete charting of the existing theory and approaches has been done in Table1.

\begin{tabular}{|c|c|c|c|}
\hline $\begin{array}{l}\text { Sr. } \\
\text { No. }\end{array}$ & Experts & Year & Contributions \\
\hline 1. & Suparna k. [4] & 2005 & $\begin{array}{l}\text { India ASEAN cooperation in services - } \\
\text { An Overview }\end{array}$ \\
\hline 2. & Mukul Ga. [11] & 2008 & A trading Cross the way of Bengal \\
\hline 3. & ASEAN S. [6] & 2009 & $\begin{array}{l}\text { Road Map for an ASEAN community } \\
(2009-15)\end{array}$ \\
\hline 4. & Pal et. al. [7] & 2009 & $\begin{array}{l}\text { THE ASEAN-India Free Trade } \\
\text { Agreement: An Assessment }\end{array}$ \\
\hline 5. & Das [14] & 2010 & India-ASEAN : Trade in Goods \\
\hline 6. & Ahmed S. [12] & 2010 & $\begin{array}{l}\text { India-ASEAN free trade agreement: A } \\
\text { SectoralAnalysi }\end{array}$ \\
\hline
\end{tabular}


International Journal of Trend in Scientific Research and Development (IJTSRD) ISSN: 2456-6470

\begin{tabular}{|c|c|c|c|}
\hline 7. & D.FICCI [15] & 2011 & $\begin{array}{l}\text { India ASEAN Free Trade Agreement: } \\
\text { Implications for India's for India's } \\
\text { Economy }\end{array}$ \\
\hline 8. & B. Today[13] & 2013 & Highway to Prosperity \\
\hline 9. & Naveen S. [3] & 2015 & $\begin{array}{l}\text { Bilateral Trade between India and ASEAN } \\
\text { : An Analytical Study } 1991-2013\end{array}$ \\
\hline 10. & Naveen S.[9] & 2016 & $\begin{array}{l}\text { Statiscal Analysis of India's Export } \\
\text { South East Asia 2000-13 }\end{array}$ \\
\hline
\end{tabular}

\section{DATA IMPACT AND ANALYSIS}

The data is taken from this observations is from various years exports details with different view. These data are custom build solutions that had been already successfully installed in the ASEAN environment. In this view of this fact, an experimental validation of the proposed model for Export evaluation has been carried out using sample tryouts. In order to validate proposed export estimation, the value of exports scenario are available by using [3] data set for following 23 years in table 2 .

Table 2: Contribute ASEAN in India's Exports

\begin{tabular}{|l|l|l|}
\hline Year & $\begin{array}{l}\text { India's Export to WORLD } \\
\text { US \$Billion }\end{array}$ & $\begin{array}{l}\text { India's Export to ASEAN } \\
\text { US \$Billion }\end{array}$ \\
\hline 1991 & 17.9 & 1.01 \\
\hline 1992 & 20.72 & 1.37 \\
\hline 1993 & 22.24 & 1.65 \\
\hline 1994 & 26.33 & 1.84 \\
\hline 1995 & 32 & 2.7 \\
\hline 1996 & 33.5 & 2.85 \\
\hline 1997 & 34.79 & 2.46 \\
\hline 1998 & 33.21 & 1.63 \\
\hline 1999 & 36.7 & 2.23 \\
\hline 2000 & 42.35 & 2.66 \\
\hline 2001 & 43.88 & 3.32 \\
\hline 2002 & 50.1 & 4.51 \\
\hline 2003 & 59.36 & 5.07 \\
\hline 2004 & 75.9 & 7.55 \\
\hline 2005 & 100.35 & 10.28 \\
\hline 2006 & 121.2 & 12.37 \\
\hline 2007 & 145.9 & 13.82 \\
\hline 2008 & 181.86 & 19.43 \\
\hline 2009 & 176.76 & 17.9 \\
\hline & & \\
\hline & & \\
\hline
\end{tabular}


International Journal of Trend in Scientific Research and Development (IJTSRD) ISSN: 2456-6470

\begin{tabular}{|l|l|l|}
\hline 2010 & 220.41 & 22.13 \\
\hline 2011 & 301.48 & 29.04 \\
\hline 2012 & 279.56 & 35.95 \\
\hline 2013 & 336 & 41.86 \\
\hline
\end{tabular}

It is evident from literature survey that ASEAN Exports is not a new term; rather it has been in discussion among the country at various forums, but there is no commonly accepted comprehensive and complete analysis available to estimating the exports of ASEAN.

\section{CORRELATIONS ESTABLISHMENT}

The figure1 describes the Indian Exports relationship with India's exports to world and ASEAN.

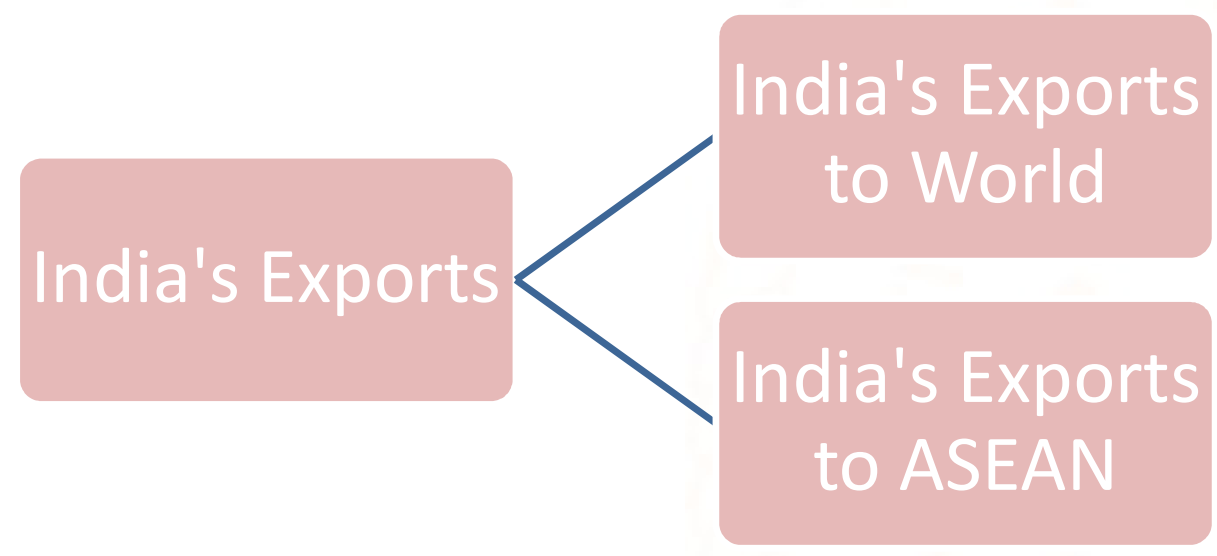

Fig.1 Correlation between Two Entities

\section{STATISTICAL ANALYSIS}

In order to establish a evaluation with multiple linear regression techniques have been used. The proposed multivariate model takes the following form:

$\mathrm{X}=\alpha 0+\alpha 1 \mathrm{Y} 1+\alpha 2 \mathrm{Y} 2+\alpha 3 \mathrm{Y} 3+\ldots \ldots \ldots \alpha \mathrm{nYn}$

Where

- $\mathrm{X}$ is dependent variable

- Y1 Y2 Y3 \& Yn are independent variables.

- $\alpha 1, \alpha 2, \ldots \alpha \mathrm{n}$

- $\alpha_{0}$ are the intercept

Developed equation $\mathrm{X}=-1.750+.119 \mathrm{Y}$ and the value of regression coefficient of India's exports to ASEAN on total exports of India to the world is significant.

The descriptive table 3 is very important for further research work. It gives the valuable record of descriptive statistics that are mean, standard deviation and number of samples selected for model validation. 
Table 3 Descriptive Analysis

\begin{tabular}{|l|l|l|l|}
\hline & Mean & Std. Deviation & N \\
\hline IEA & 10.5926 & 11.87800 & 23 \\
\hline IEW & 104.0217 & 98.91904 & 23 \\
\hline
\end{tabular}

Pearson's coefficient of correlation technique was used for estimating the degree of correlation among variables. The value of correlation ' $r$ ' lies between \pm 1 , positive value of ' $r$ ' in table 4 is a sign of positive correlation between the two variables.

Table 4 Correlation

\begin{tabular}{|l|l|l|l|}
\hline \multicolumn{2}{|c|}{} & IEA & IEW \\
\hline $\begin{array}{l}\text { Pearson } \\
\text { Correlation }\end{array}$ & IEA & 1.000 & .988 \\
& IEW & .988 & 1.000 \\
\hline
\end{tabular}

Summary table 5 for Export Environment correlation of fig. 1 proves that all the three selected metrics are statistically significant at confidence level of $95 \%$. Table 6 explain coefficient evaluation of exports scenario. Table 5 Model Summary

\begin{tabular}{|l|l|l|l|l|l|}
\hline Model & $\mathbf{R}$ & $\mathbf{R}$ Square & $\begin{array}{l}\text { Adjusted } \\
\text { Square }\end{array}$ & $\begin{array}{l}\text { Std. Error of the } \\
\text { Estimate }\end{array}$ & Sig .F Change \\
\hline $\mathbf{1}$ & $\mathbf{. 9 8 8}^{\mathrm{a}}$ & $\mathbf{. 9 7 6}$ & $\mathbf{. 9 7 5}$ & $\mathbf{1 . 8 6 5 4 2}$ & $\mathbf{0 0 0}$ \\
\hline \multicolumn{2}{|l}{ Predictors: (Constant), IEW } & & \\
\hline
\end{tabular}

Table 6 Coefficient of Equation

\begin{tabular}{|c|c|c|c|c|c|c|c|}
\hline \multicolumn{2}{|c|}{ Model } & \multicolumn{2}{|c|}{$\begin{array}{l}\text { Un standardized } \\
\text { Coefficients }\end{array}$} & \multirow[t]{2}{*}{$\begin{array}{l}\text { Standardized } \\
\text { Coefficients }\end{array}$} & \multirow{2}{*}{$\begin{array}{l}\mathrm{t} \\
\mathbf{- 3 . 0 6 4}\end{array}$} & \multirow{2}{*}{$\begin{array}{l}\text { Sig. } \\
\text {.006 }\end{array}$} & Correlations \\
\hline \multirow[t]{3}{*}{1} & Constant & B & $\begin{array}{l}\text { Std. } \\
\text { Error }\end{array}$ & & & & \multirow{3}{*}{.988} \\
\hline & \multirow[t]{2}{*}{ IEW } & -1.750 & .571 & \multirow[t]{2}{*}{0.988} & \multirow[t]{2}{*}{29.512} & \multirow[t]{2}{*}{.000} & \\
\hline & & .119 & .004 & & & & \\
\hline \multicolumn{4}{|c|}{ Dependent Variable: IEA } & & & & \\
\hline
\end{tabular}

\section{Statistical Test}

Statistical Test of India's Exports significant with two others which are shown in figure 1. It is essential to test the validity of proposed model for acceptance. 2 sample $t$ tests apply for check the impact between IEW (Indian Exports with Worlds) and IEA (Indian Exports with ASEAN). 2t-test is handy hypothesis tests in statistics when compare means. 
International Journal of Trend in Scientific Research and Development (IJTSRD) ISSN: 2456-6470

Table 72 t- test between IEW (Indian Exports with Worlds) and IEA (Indian Exports with ASEAN)

\begin{tabular}{|c|c|c|c|c|c|}
\hline \multicolumn{6}{|c|}{ Paired Samples Statistics } \\
\hline & & Mean & $\mathrm{N}$ & Std. Deviation & Std. Error Mean \\
\hline \multirow[t]{2}{*}{ Pair 1} & IEW & 104.0217 & 23 & 98.91904 & 20.62605 \\
\hline & IEA & 10.5926 & 23 & 11.87800 & 2.47673 \\
\hline
\end{tabular}

Null hypothesis (H0): There is no significant difference between IEW (Indian Exports with Worlds) and IEA (Indian Exports with ASEAN)

H0: $\mu 1-\mu 2=0$

Alternate hypothesis (HA): There is significant difference between IEW (Indian Exports with Worlds) and IEA (Indian Exports with ASEAN)

HA: $\mu 1-\mu 2 \neq 0$

In the above hypothesis $\mu 1$ and $\mu 2$ are treated as sample means of population. Mean value and Standard Deviation value have been calculated for specified two samples and represented in table 7. Correlation comes out to be 0.988, that shows the IEW (Indian Exports with Worlds) and IEA (Indian Exports with ASEAN) is highly correlated. The hypothesis is tested with zero level of significance and $95 \%$ confidence level. The $p$ value is 0.006 . Therefore alternate hypothesis accepted and null hypothesis is discarded.

\section{Critical Impacts}

This study shows the importance of Indian exports in general and as a key factor to ASEAN (X) and World (Y) for producing high effective with ASEAN environment. As a result we can conclude without any loss of generality that Indian Exports is essential and applicable in the ASEAN country with p value considerations.

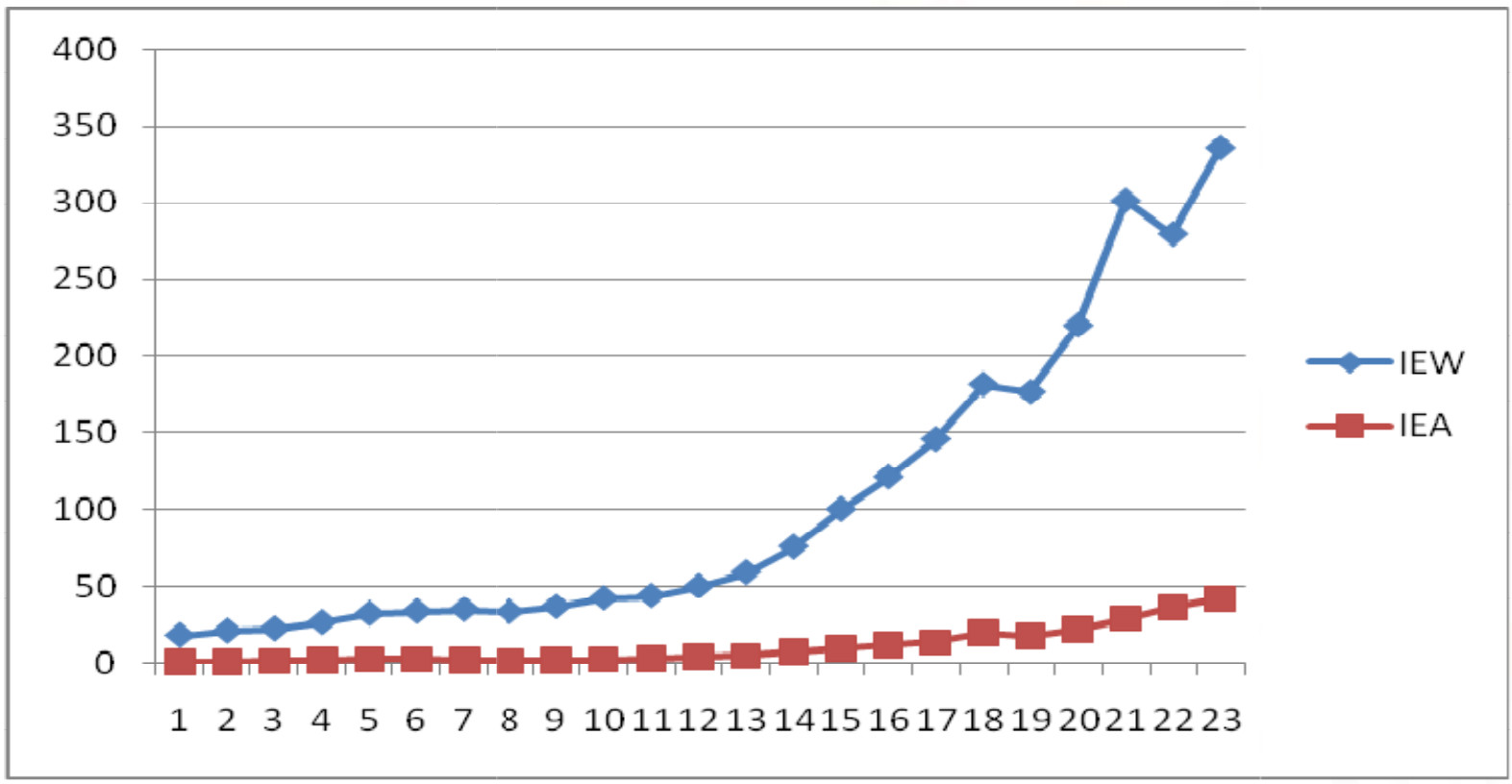

Fig 2. Study analysis amoung IEW (Indian Exports with Worlds) and IEA (Indian Exports with ASEAN)

\section{CONCLUSION}

The outcome is that the colossal and substantive business connects amongst India and Southeast Asia constituted a critical segment of the advanced period exchange. Since India has encountered maintained economical development in this way there is vast potential for the extension of India-Southeast Asia stock exchange which has stayed undiscovered up until now. In the current time Southeast Asia has indicated incredible dynamism regarding exchange with India and additionally the exchange amongst 
India and Southeast Asia has demonstrated the noteworthy relationship measurably amid the time of study. This paper has break down of IEA (Indian Exports with ASEAN) utilizing the strategy of different direct relapses. Factual examination demonstrates that this assessment is measurably particularly affect and adequate. This paper analyzes approves the measuring capacity of exhibited investigation. That Empirical approval examination on this exploration work demonstrates that IEA (Indian Exports with ASEAN) is standard approach, more down to earth in nature and helps the product business in venture positioning.

\section{REFFERENCES}

1. Asian development Bank, "Emerging Asian Regionalism', Manila 2010.

2. Lee H. and Liew, "India-ASEAN -55 Economic Integration: Impact of Liberalization",

IUP Journal of Applied Economics, Volume 6, Issue 6, Pages 7-20, 2007.

3. Naveen S., "Bilateral Trade between India and ASEAN: An Analytical Study 1991-2013”,

International Journal in Management and Social Science, Pages 221-232, 2015.

4. Suparna Karmakar, India ASEAN cooperation in services - An Overview, ICRIER Working paper No,2005, 176.

5. Tai H., "ASEAN discovers India', Wall Street Journal, 2010.
6. Onafowara, "Can Trade Liberalization Stimulate Economic Growth in Africa? World Development" Pages 497-506, 1998.

7. ASEAN Secretariat, "Road Map for an ASEAN Community”, Jakarta, 2009.

8. Pal, P. and M. Dasgupta, "THE ASEAN-India Free Trade Agreement: An Assessment", Volume 10, No. 38, 2009.

9. Naveen sood, "Statistical Analysis of India's Export to South East Asia 2000-13" International Journal of Applied Research, 2016.

10. R. Chandra, "Understanding India's Regional Initiative with in ASIA", ISAS working Paper, 2008.

11. Mukul GA, "A trading Cross the way of Bengal", ISEAS, 2008.

12. Ahmed, S., "India-ASEAN free Trade Agreement: A Sectored Analysis" SSRN Working Paper, 2010

13. Agreement Dash, 'India-ASEAN : Trade in Goods”, SME Times, New Delhi, India, 2010.

14. Deloitte-FICCI, "India ASEAN Free Trade Agreement: Implications for India's for India's Economy"' Deloitte-FICCI White paper, 2011.

15. Business Today, Highway to Prosperity page 16 May, 2013. 